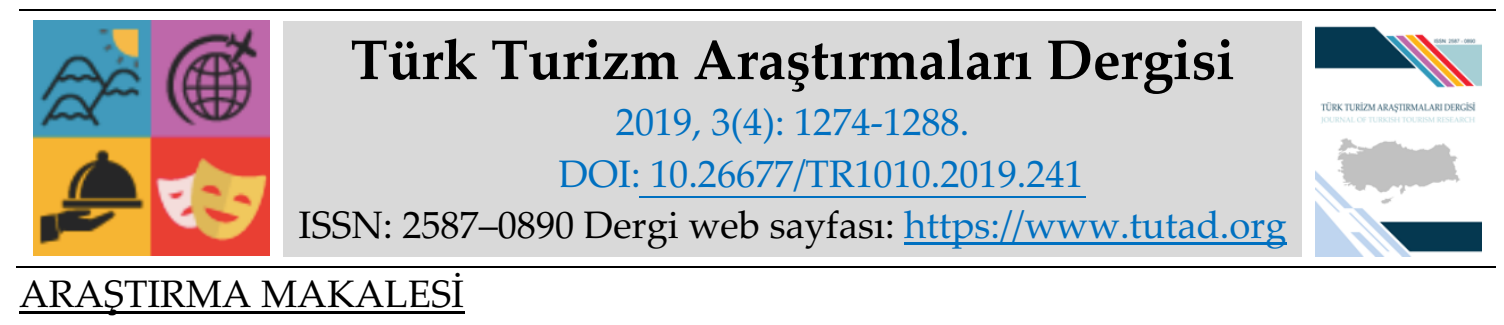

\title{
Çömlekçilik (Guduculuk) El Sanatının Sürdürülebilir Turizm Kapsamında İncelenmesi: Gümüşhane Dölek Köyü Örneği*
}

Öğr. Gör. Dr. Murat ÖDEMIŞ, Gümüşhane Üniversitesi, Turizm Fakültesi, Gümüşhane, e-posta: mrodemis@gmail.com

ORCID: https://orcid.org/0000-0003-3636-8344

Dr. Öğr. Üyesi, İsmail ÇALIK, Gümüşhane Üniversitesi Turizm Fakültesi, Gümüşhane, e-posta: ismailcalik29@gmail.com

ORCID: https://orcid.org/0000-0001-9815-5796

Öz

Somut olmayan kültürel miras unsurları kapsaminda incelenen el sanatları, günümüzde yok olmaya başlayan değerler arasında yer almaktadır. Diğer taraftan, Gümüşhane ili Dölek Köyü'nde üretimi sınırlı da olsa halen devam etmekte olan çömlekçilik (guduculuk), akademik olarak incelenmesi gereken değerli bir el sanatıdır. Bu doğrultuda çalışmanın amacı, Gümüşhane ili Dölek Köyü'nde üretimi giderek azalan guduculuğun sürdürülebilir turizm bağlamında tekrar canlandırılmasına ve gelecek nesillere aktarılmasına yönelik çözüm önerileri sunmaktır. Çalışmanın amaçları doğrultusunda; ilgili paydaşlarla görüşmeler gerçekleştirilmiş olup, ortaya çıan sonuçlar betimsel analiz yöntemiyle analiz edilmiştir. Sonuç olarak çalışmada, guduculuğun devam ettirilmesi noktasında birtakım problemlerin var olduğu tespit edilmiştir. $\mathrm{Bu}$ problemlerin başlıcaları; gençlerin el sanatına karşı ilgisizliği ve el sanatı ustalarının emeklerinin karşılığını yeterince alamamasıdır. Ayrıca, üretim sürecinin zor ve zahmetli olması, kooperatifleşmeye gidilmediği için guduların ucuza satılması, Dölek Köyü'nde guduların satışı ve pazarlanması için uygun mekânların olmaması diğer problemlerdir.

*Bu çalışmanın özeti, 16-18 Ekim 2017 tarihinde düzenlenen I. Uluslararası Gümüşhane Sempozyumu'nda sözlü olarak sunulmuştur.

Anahtar Kelimeler: Somut Olmayan Kültürel Miras Unsurları, Guduculuk El Sanatı, Sürdürülebilir Turizm, Gümüşhane İli Dölek Köyü.

Makale Gönderme Tarihi: 19.05.2019

Makale Kabul Tarihi: 02.10.2019

\section{Önerilen Atıf:}

Ödemiş, M. ve Çalık, İ. (2019). Çömlekçilik (Guduculuk) El Sanatının Sürdürülebilir Turizm Kapsamında İncelenmesi: Gümüşhane Dölek Köyü Örneği, Türk Turizm Araştırmaları Dergisi, 3(4): 1274-1288.

(C) 2019 Türk Turizm Araştırmaları Dergisi. 


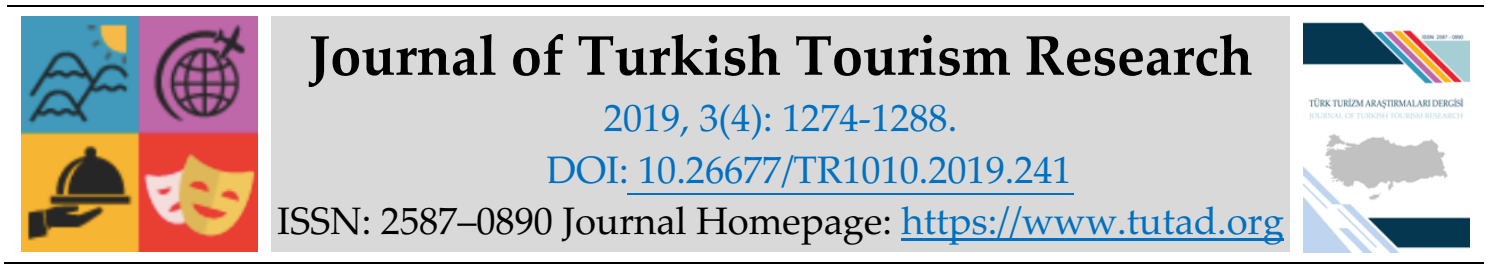

\title{
$\underline{\text { RESEARCH PAPER }}$
}

\section{Investigation of Pottery Handicraft in the Scope of Sustainable Tourism: The Case of Gumushane Dölek Village}

Dr. Murat ÖDEMIŞ, Gümüşhane University, Faculty of Tourism, Gümüşhane, e-mail: mrodemis@gmail.com

ORCID: https://orcid.org/0000-0003-3636-8344

Assistant Prof. Dr. İsmail ÇALIK, Gümüşhane University Faculty of Tourism, Gümüşhane, email: ismailcalik29@gmail.com

ORCID: https://orcid.org/0000-0001-9815-5796

\begin{abstract}
Handicrafts that are examined within the context of intangible cultural heritage are among the values that are beginning to disappear. On the other hand; guduculuk, which is still going on even if limited its production in Dolek Village of Gumushane province, is a valuable hand craft to be examined academically. In this respect, the aim of study is to provide a solution for the revitalization and transfering it to future generations in the context of sustainable tourism of guduculuk increasingly decreasing production in the village of Dolek, Gumushane province. In line with the aims of the work; interviews with relevant stakeholders were conducted and the results were analyzed and evaluated by content analysis and descriptive analysis method. As a result, it has been found that there are some problems in the continuation of guduculuk in the study. These problems are mainly young people's indifference to the handcraft and not get craftsman's labor provision. In addition, the production process is difficult and laborious, the sale of potteries cheaply for the lack of become a cooperative, the lack of suitable places for the sale and marketing of pottery in Dölek Village are other problems.
\end{abstract}

Keywords: Intangible Cultural Heritage Elements, Guduculuk Hand Crafted, Sustainable Tourism, Dölek Village of Gumushane Province.

Received: 19.05 .2019

Accepted: 02.10.2019

\section{Suggested Citation:}

Ödemiş, M. and Çalık, İ. (2019). Investigation of Pottery Handicraft in the Scope of Sustainable Tourism: The Case of Gumushane Dölek Village, Journal of Turkish Tourism Research, 3(4): 12741288.

(C) 2019 Türk Turizm Araştırmaları Dergisi. 


\section{Gíriş}

Somut olmayan kültürel miras kavramı; sürdürülebilir kalkınmanın güvencesi (UNESCO, 2003) ve toplumların kültürel kimliklerinin korunması için bir araç olarak görülmekte olup (Leimgruber, 2010), sürdürülebilir turizm kavramı içerisinde incelenen ve değerlendirilen bir konudur (Labadi, 2013). Önceden folklor, geleneksel ve popüler kültür vb. isimlerle anılan günümüzde ise uzmanların önceki kavramların yerine kullanılmak üzere tek bir ortak isim üzerinde uzlaşmaya vardığı somut olmayan kültürel miras kavramı (Kurin, 2004); geleneksel el sanatları başta olmak üzere toplumların sosyal ve kültürel birikimlerini, ağızdan ağıza yayılan standartlarını ve değerlerini içermektedir (UNESCO, 1989). Somut olmayan kültürel miras unsurları arasında yer alan yöresel el sanatları, turizm vasıtasıyla korunabilecek önemli değerler arasında yer almaktadır.

Bu noktada sürdürülebilir turizm; yerel ürünler içinde yöreye ait el sanatlarının sergilenmesi ve turistlere sunulması, yöresel el sanatlarına ekonomik değer kazandırılmasını ve bu el sanatlarının gelecek nesillere aktarılmasını mümkün kılabilecek bir araç olarak kabul edilebilir (Demirbulat vd., 2015). Nitekim yerel halkın ekonomik kazanımlarının artırılmasına odaklı bir şekilde turistik bir değere dönüştürülen el sanatları yerel halk tarafından da sahiplenilebilmektedir. Bu anlamda söz konusu el sanatının orijinal özelliklerinin mümkün olduğunca korunması, ziyaretçilere özenli bir şekilde sunulması ve turistler tarafından tecrübe edilmesinin sağlanması oldukça önemlidir (Türker ve Çelik, 2012). Diğer taraftan, söz konusu el sanatlarının ve diğer somut olmayan kültürel miras unsurlarının bu şekilde ekonomik bir metaya dönüştürülmesiyle beraber özellikle genç nesil arasında yalnızca maddi değeri açısından sahip çıkılmaya değer görülmesi ve manevi değerini yitirmeye başlaması gibi birtakım sosyo-kültürel problemlerin ortaya çıkması da söz konusu olabilmektedir.

Yöresel el sanatları ve bu kapsamda yer alan çömlekçilik, Türkiye genelinde özellikle kırsal turizm (Ceylan, 2014) ve/veya kültür turizmi (Can, 2013) bağlamında değerlendirilebilecek önemli turistik çekicilik unsurları arasında yer almaktadır. Ancak çömlekçilik el sanatı da, diğer el sanatları gibi, yok olma tehlikesiyle karşı karşıya olan yöresel değerler arasında yer almaktadır. Bu nedenle çömlekçilik el sanatının manevi ve otantik değeri yok edilmeksizin, planlı ve bilinçli bir şekilde ekonomik değere dönüştürülerek koruma altına alınması gerekmektedir. Özellikle Gümüşhane Dölek Köyü'nde sürdürülmekte olan "guduculuk" olarak isimlendirilen çömlekçilik el sanatının, bu kapsamda incelenmesi ve değerlendirilmesi gerekmektedir.

Bu bağlamda çalışmada; Gümüşhane ili Dölek Köyü'nde sınırlı da olsa üretimi halen devam ettirilmekte olan guduculuğun eskiye göre durumunun, gelecek nesillere aktarılmasında yaşanan güçlüklerin, üretim sürecinin, kullanım alanlarının ve özgün niteliklerinin ortaya konulması amaçlanarak, görüşme metinlerinde ortaya çıkan sonuçlar çerçevesinde guduculuk el sanatının korunmasına yönelik öneriler sunulmuş ve turizmin bu anlamdaki rolü tartışılmıştır. $\mathrm{Bu}$ doğrultuda ilgili paydaşlarla görüşmeler gerçekleştirilmiş olup, ortaya çıan sonuçlar betimsel analiz yöntemiyle analiz edilerek gerekli değerlendirmeler yapılmıştır.

\section{KAVRAMSAL ÇERÇEVE}

\section{Somut Olmayan Kültürel Miras Kavramı ve El Sanatları}

Somut olmayan kültürel mirasın, kültürel çeşitliliğin kaynağı olmakla beraber sürdürülebilir kalkınmanın garantisi olduğu düşüncesi, 2001 yılındaki UNESCO Kültürel Çeşitlilik Evrensel Bildirgesi'nde ve 2002 yılında Kültür Bakanları tarafından kabul edilmiş olan İstanbul Bildirgesi'nde benimsenmiştir (UNESCO, 2003). 
Önceleri somut olmayan kültürel miras kavramı; kültür çalışmaları yapanlar ve bilim insanları tarafından folklor, sözlü miras, geleneksel kültür, açıklayıcı kültür, yaşam tarzı, etnografik kültür, toplum temelli kültür, adetler, yaşayan kültürel miras, popüler kültür gibi çok farklı isimlerle anılmaktaydı. Ancak sonraki dönemlerde, uzmanlar arasında tüm bu kavramlarla aynı anlamı taşıyan ortak bir kavram olarak somut olmayan kültürel miras kavramı üzerinde uzlaşma sağlanmıştır (Kurin, 2004). Somut olmayan kültürel miras; soyut, manevi ve kayıt altın alınması güç olan unsurlardan oluşmaktadır. Somut olmayan kültürel miras unsurlarının ilk bakışta algilanması somut mirasa göre daha zor olabilmektedir. Somut olmayan kültürel miras unsurlarına bir ülke ya da yörenin sahip olduğu dil, dans, iş yapma becerileri, yetenekler, geleneksel bazı davranışlar, el sanatları, yiyecek-içecek kültürü örnek olarak verilebilir (Öter ve Ünal, 2011).

Nesilden nesile aktarılan somut olmayan kültürel miras unsurları, toplulukların ve grupların doğayla ve tarihleriyle etkileşimleri doğrultusunda, devamlı bir şekilde yeniden oluşturulur ve bu durum söz konusu topluluk ya da gruplara kimlik ve devamlılık duygusu aşılar. Böylelikle kültürel çeşitliliğe ve insan yaratıcılığına olan saygıya katkıda bulunulmuş olur. Somut olmayan kültürel miras kapsamında; sözlü gelenek ve anlatımlar (destanlar, efsaneler, halk hikayeleri, atasözleri, masallar, fıkralar vb.), gösteri sanatları (karagöz, meddah, kukla, halk tiyatrosu vb.), toplumsal uygulamalar, ritüeller ve şölenler (nişan, düğ̈̈n, doğum, nevruz vb. kutlamalar), doğa ve evrenle ilgili bilgi ve uygulamalar (geleneksel yemekler, halk hekimliği, halk takvimi, halk meteorolojisi vb.), el sanatları geleneği (dokumacılık, nazar boncuğu, telkari, bakırcılık, halk mimarisi) yer almaktadır (Kültür ve Turizm Bakanlığı, 2017).

Somut olmayan kültürel miras kapsamında yer alan el sanatları; toplumun duygularını, yaşamış oldukları hayatın izlerini kolaylıkla aktarabildikleri önemli araçlardan birisidir. Böylelikle bu ürünler yaşadıkları ve üretildikleri döneme, olaylara tanıklık edebilmektedir. Teknolojik gelişmeler ve toplumsal değişmelere rağmen el sanatları Anadolu'nun bazı köy ve kasabalarında hala sürdürülmektedir. El sanatlarının icra edilmesiyle ortaya çıkan ürünler her ne kadar somut olsa da, bu ürünleri yaratan kişilerin duygu, düşünce ve yaşadıkları olayların toplumsal özelliklerinin motif, renk, biçim vb. aracılığıyla yansıtılması sebebiyle soyut özelliğe sahiptir. Bu özellik, el sanatlarının somut olmayan kültürel miras kapsamında değerlendirilmesinin en önemli nedenidir (Onuk ve Akpınarlı, 2004: 5).

\section{Gümüşhane'de Çömlekçilik (Guduculuk) El Sanatı}

Binlerce yıldır insanoğlu pişmiş toprak üretmekte ve kullanmaktadır. Ancak üretimi ve kullanımı eskisine göre çoğu alanda artık hayatımızı terk etmiştir. Anadolu'da hala geleneksel çömlek üretiminin gerçekleştirildiği merkezler vardır. Ancak üretimine devam eden bu merkezler birtakım sorunlar yaşamaktadır. Yaşanan problemlerin en önemlisi, üretimin devamlılığ sorunudur. Bu noktada, çömlek üretim atolyelerinin varlığını sürdürerek korunabilmesi oldukça önemlidir (Buner ve Okca, 2016).

Gümüşhane'de halk arasında gudu ya da gudi olarak isimlendirilen güveçler, hem bir yemek çeşidini hem de yemeğin pişirildiği kabı ifade etmektedir (Gümüşhane Valiliği, 1999; Ülker ve diğerleri, 2011: 400; Çalık vd., 2013: 12). Genel olarak Gümüşhane ili merkezine bağlı Dölek Köyü'nde güveç adı altında su testisi, küp, kırıs, gudu, kıyılı ve çanak çeşitlerinin üretimi gerçekleştirilmektedir (Gümüşhane Valiliği, 1999: 207). Ayrıca çeşitli yemeklerin pişirildiği gudu ya da diğer adıyla güveçler, doğal yöntemler kullanılarak çok başarılı ve sağlıklı yemekler pişirilmesine olanak tanımaktadır (Akyol, 2012). 
Çömlek, gudu ya da güveç adı altında topraktan üretimi gerçekleştirilen ürünlerin üretiminin genel olarak üç aşamadan oluştuğu söylenebilir. Birinci aşamada hammaddenin getirilmesi ve işlenmeye hazırlanması, ikinci aşamada biçimlendirme işlemi, üçüncü aşamada ise biçimlendirilen ürünün pişirilmesi aşaması yer almaktadır (Baykal, 1990). Gümüşhane Dölek Köyü'nde pişirilen guduların sağlamlığını koruması, çatlamaması ve toprak kokusunun yemeğe geçmemesi için sütle sırlama/zilleme işlemi de yapılmaktadır (Özkul Fındık ve Köşklü, 2013: 58).

Gümüşhane' de topraktan yapılan gudularda pişirilen yiyeceklerin tüketilmesi özellikle Ramazan aylarında kültürel bir ritüel konumundadır. İftarlarda yöresel yiyecekler gudularda hazırlanarak misafirlere sunulur. Gudular köy kadınları tarafından üretilmekte ve bu el sanatı anadan kıza öğretilerek gelecek nesillere aktarılmaktadır (Gümüşhane Valiliği, 2009: 139). Ayrıca, geçmişte Dölek Köyü'nde guduculuğu kadınların yapması nedeniyle diğer köylere kız verilmediği söylenmektedir (Albayrak, 2013: 42). Guduların kadınlar tarafından elle şekil verilerek üretilmesi kadınlar arasındaki (anne/kız, gelin/kaynana) gelenek aktarımına dayanmaktadır (Özkul Fındık ve Köşklü, 2013: 56).

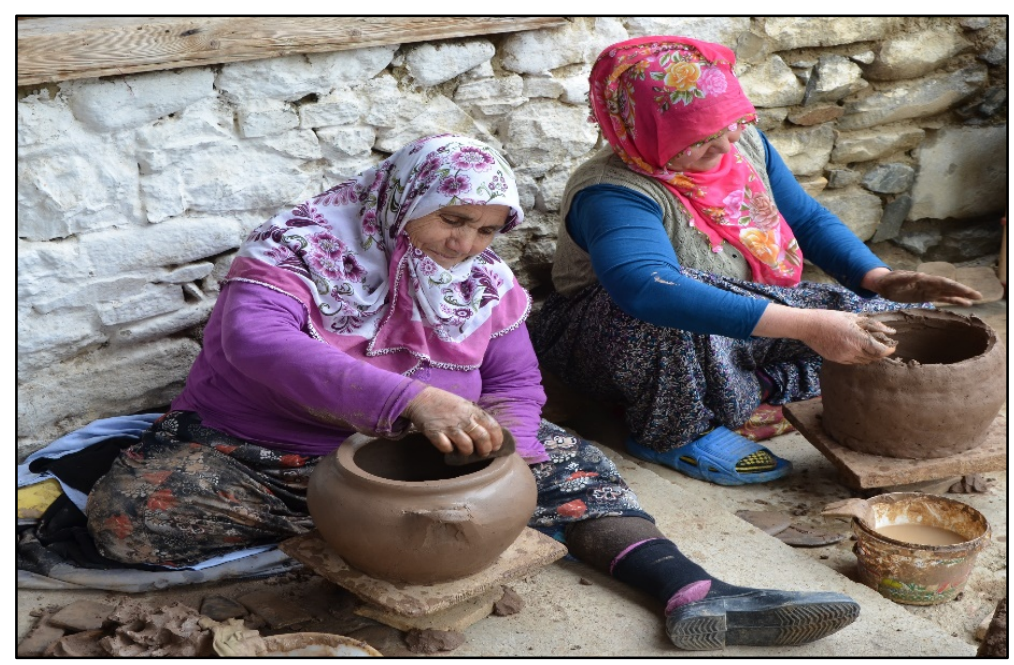

Fotoğraf 1. Gudulara Şekil Verme Aşaması

Kaynak: 21 Haziran 2016 tarihinde gerçekleştirilen uygulama gezisinde yazarlar tarafından fotoğraflanmıştır.

Gümüşhane'de meyve ticaretinden sonra, önemli bir ekonomik etkinlik olarak, çanakçömlekçilik gelirdi. Tarihsel süreç içerisinde Dölek Köyü'nde otuz- kırk bin gudunun üretildiği anlatılmaktadır (Erdener, 1997: 65). Buna karşılık, 90'lı yıllarda 30-40 kadın tarafından sürdürülen guduculuk el sanatının (Türkfiliz, 1997: 10), günümüzde yalnızca 10 kişi tarafından icra edildiği köylüler tarafından belirtilmektedir. Dolayısıyla Dölek Köyü'nde guduculuğu devam ettiren kadınların sayısının günden güne azaldığı söylenebilir.

\section{Sürdürülebilir Turizm ve Çömlekçilik (Guduculuk) El Sanatı}

Günümüzde sürdürülebilirlik kavramı dünyada oldukça fazla tartışılan bir konuya dönüşmüş durumdadır. Son yıllarda ise sürdürülebilirlik kavramı hemen hemen tüm alanlarda etkisini hissetirmeye başlamıştır. Sosyal bir gereklilik olarak ortaya çıkan sürdürülebilirlik kavramı; tarım, kent, turizm, teknoloji gibi birçok alanda tartışılan ve uygulanmaya çalışılan bir konudur. Toplumsal boyutları farklı farklı olan bu alanların ortak özellikleri, sürdürülebilirlik bağlamında insanın geleceğini konu almaları ve söz konusu alana ilişkin kaynakların korunmasını amaç edinmeleridir (Beyhan ve Ünügür, 2005). Bilhassa turizm; bir ülkenin ya da bir yörenin kültürel 
kaynaklarının korunmasına katkıda bulunabilmektedir. Somut olmayan kültürel miras kapsamında yer alan el sanatları, Türkiye'de önemli bir kültürel birikimi oluşturmaktadır. Dolayısıyla el sanatları dahil diğer tüm kültürel birikimin korunabilmesi ve gelecek nesillere aktarılabilmesi, sürdürülebilir ilkeler çerçevesinde hareket edilmesine bağlıdır. Turizm etkinlikleri çerçevesinde toplumsal değerlerin korunması ise, güncel bir kavram olan "sürdürülebilir turizm" kapsamında tartışılmakta olan bir konudur.

Sürdürülebilir turizm nispeten yeni bir kavram olarak, destinasyonlar üzerindeki olumsuz sosyo-kültürel ve çevresel değişimleri azaltmayı, destinasyonların yaşam süresini uzatmayı ve yerel halk için eşsiz ekonomik firsatlar oluşturmayı amaçlayan bir turizm türü olarak ifade edilebilir. Bu yaklaşım, küresel anlamda çekicilik arz eden destinasyonlarda sosyo-kültürel ve doğa ile ilgili faaliyetler talep eden turist kitlesinin beklentileri ile de uyum göstermektedir (Hassan, 2000). Ayrıca sürdürülebilir turizm, toplum içerisindeki farklı paydaş ve çıar gruplarını bir araya getirerek turizm faaliyetlerinin en uygun düzeyde ve planlı bir şekilde sürdürülebilmesini amaçlamaktadır (Hunter, 1997; Hardy ve Beeton, 2001).

Sürdürülebilir turizmin geniş ve küçük ölçekli hedeflerine göre iki farklı perspektife sahip olduğu söylenebilir. Sürdürülebilir turizmin geniş ölçekli perspektifinde; turizmin global etkileri, ekolojk/fiziksel etkiler, çevresel yönetim sistemleri, çevresel etki değerlendirme, çevresel denetim, yeniden kullanım/geri dönüşüm/azaltım, sürdürülebilir turizm rehberleri, eşitlik, şirket/organizasyon hedefleri gibi fiziksel/ekolojik çevre odaklı konular yer almaktadır. Sürdürülebilir turizmin küçük ölçekli perspektifinde ise; yerel bölgenin kimliğine odaklanma, eşitlik, sürdürülebilir turizm rehberleri, yerel kontrol, yerel sakinlerin/turistlerin eğitimi, turistlerin karakteristik özellikleri, orijinallik, bütünlük, sosyal/kültürel etkiler ve destinasyon/yerel etkiler gibi yerel veya destinasyon odaklı bir bakış açısı hakimdir (Clarke, 1997).

Birçok araştırmacı tarafından sürdürülebilir turizm gelişiminin; ekolojik açıdan sorumlu, sosyal koşullara uyumlu, kültürel açıdan uygun, politik olarak eşit, teknolojik olarak destekleyici ve ayrıca ev sahibi toplum için ise ekonomik açıdan uygulanabilir olan uyumlaştırılmış bir gelişim yolunu desteklediği kabul edilmektedir (Choi ve Sirakaya, 2005). Ancak bu süreçte sürdürülebilir turizm uygulamalarının başarısı, doğru ve güvenilir göstergeler yoluyla ölçülmelidir. Böylece turizmin başlangıçtaki ve yıllar sonraki etkileri karşılaştırmalı olarak değerlendirilerek turizm faaliyetlerinin sürdürülebilir olup olmadığına karar verilebilir (Butler, 1999). Bu anlamda Birleşmiş Milletler Dünya Turizm Örgütü'nün (2004) belirlemiş olduğu sürdürülebilir turizm göstergeleri destinasyonlar için önemli bir rehber niteliğine sahiptir. Bu kaynakta turizm ve el sanatları ilişkisi farklı açlardan ele alınmaktadır. Turizmin geleneksel miras unsurlarının korunmasındaki rolü (UNWTO, 2004: 278), yerel halkın turizm gelişiminden memnuniyeti ve kabul edebilirlik seviyesi göstergesi altında el sanatları ustalarının ustalık değeri karşılığını ekonomik olarak alıp almadığı (UNWTO, 2004: 264) gibi göstergelere yer verilmektedir.

Diğer yandan sürdürülebilir turizmin, somut olmayan kültürel miras unsurlarının korunmasını ve gelecek nesillere aktarılmasını sağlayarak, bu değerlerin turizm vasıtasıyla farklı kültürleri tanıma ve keşfetme beklentisi içerisinde olan ziyaretçilerle buluşturulmasına imkan verebilen önemli kavram ve uygulamalardan birisi olduğu söylenebilir (Çalık ve Ödemiş, 2015).

Günümüzde birçok el sanatının yok olmaya yüz tuttuğu görülmektedir. Yok olmaya başlayan el sanatları arasında Gümüşhane ili merkeze bağlı Dölek Köyü'nde üretimi gerçekleştirilmekte olan guduculuk (çömlekçilik) da bulunmaktadır (Turizm Bakanlığı ve Gümüşhane Valiliği, 1994: 91). Gümüşhane ili Dölek Köyü'nde sınırlı da olsa gudu üretimi halen devam ediyor olmasına rağmen; guduculuğun üretim ve pazarlama koşullarının zorluğu, gençlerin guduculuk el sanatına ilgisizliği gibi nedenlerle bu el sanatının yok olma tehlikesiyle karşı karşıya olduğu 
görülmektedir. Bu noktada turizmin, sürdürülebilir ilkeler çerçevesinde gudu ve diğer el sanatlarının sosyal, kültürel ve ekonomik değerinin uzun vadede çok daha geniş bir kesime yaygınlaştırılmasına katkıda bulunabilecek bir potansiyeli barındırdığı söylenebilir.

Turizm etkinlikleri ile el sanatlarına gereken önem verilerek ülkenin mevcut kaynakları verimli hale getirilebilmekte ve kaybolmaya yüz tutan el sanatları canlandırılabilmektedir. Turizm ve el sanatları, bir yörenin ekonomik ve kültürel olarak kalkınabilmesi noktasında işbirliği halindedir. El sanatına ait ürünler turistlerin alışverişinde ayrı bir öneme sahiptir. Ayrıca Türkiye'de turistik değer taşıyan el sanatlarının geleneksel yönü oldukça güçlüdür. Söz konusu ürünler arasında çömlekçilik el sanatı da turistik bir değer taşımaktadır (Er ve Hünerel, 2011).

\section{YÖNTEM}

Araştırmanın evrenini, Gümüşhane Dölek Köyü'nde guduculuk (çömlekçilik) el sanatını icra eden 10 el sanatı ustası oluşturmaktadır. Amaçı örneklem yöntemine göre bu el sanatı ustaları arasından seçilen ve görüşme talebimize olumlu yanıt veren 2 el sanatı ustası ile mülakatlar gerçekleştirilmiştir. El sanatı ustalarının yanı sıra konu ile ilgili derinlemesine bilgi sahibi olabilmek amacıyla farklı paydaşlardan da bilgi alınmıştır. Bu paydaşlar; guduculuk ile ilgili araştırma ve deneyimleri bulunan 2 eğitimci-yazar, 1 gazeteci-yazar, 1 köy muhtarı ve köy eşrafından 1 kişidir. Bu paydaşlardan bilgi alınmasının nedeni, el sanatları ustalarından el sanatları-turizm ilişkisi hakkında nitelikli bilgi elde edilememesidir.

\section{Veri Toplama Aracı}

Araştırmada veri toplama aracı olarak görüşme (mülakat) kullanılmıştır. Mülakatlar, randevu talebine olumlu yanıt veren el sanatı ustası, eğitimci/yazar, gazeteci, köy muhtarı ve yerel halk ile 17 Haziran 2016 ile 21 Haziran 2016 tarihleri arasında yüzyüze gerçekleştirilmiştir. Araştırma kapsamında toplamda 7 paydaşla görüşülmüştür.

Görüşme yönteminde nitelikli bir görüşme sırasında kişilerle birebir iletişime geçildiğinden; dinleme eksikliği, kişiler arasında ortaya çıkan ön yargılar gibi günlük iletişim ve etkileşim hatalarının oluşması söz konusu değildir. Dolayısıyla nitelikli bir görüşmede, iletilen mesajların doğruluğunun yüksek olduğu ve sıradan bir konuşmaya göre derinliği fazla olan konuşmaların gerçekleştirilme imkanının bulunduğu söylenebilir (Yıldırım ve Şimşek, 2008: 119). Görüşmelerin tam yapılandırılmış, standartlaştırılmış, kantitatif odaklı, yarı yapılandırılmış ve etkileşimli türleri bulunmaktadır (Holfstein ve Gubrium, 1999: 105).

\section{Veri Analiz Yöntemi}

Çalışmada, nitel veri analiz yöntemleri arasında yer alan betimsel analiz yönteminden yararlanılmıştır. Araştırmanın veri analizi kısmında ilk olarak görüşme metinleri deşifre edilmiştir. Mülakatlardan elde edilen görüşme metinleri özetlenerek 3 farklı başlık altında temalandırılarak değerlendirilmiştir. Bu başlıklar; 1-"guduculuk el sanatının eskiye göre durumu ve gelecek nesillere aktarılmasında yaşanan gü̈çükler", 2-"guduculuk el sanatının üretim süreci, kullanım alanları ve özgün nitelikleri" ve son olarak 3-"el sanatının korunması ve gelecek nesillere aktarılması ile ilgili öneriler ve bu noktada turizmin rolü"nden oluşmaktadır. Belirtilen 3 temel kategori ile ilişkili katılımclardan bilgi alınan konular Tablo 1'de yer almaktadır. Analizde katılımcılar K1, K2, K3....şeklinde kodlanmıştır. 
Tablo 1. Katılımcılara İlişkin Bilgiler

\begin{tabular}{|l|l|l|c|}
\hline & \multicolumn{1}{|c|}{ Mesleği } & \multicolumn{1}{|c|}{ Bilgi Alınan Temel Konular } & $\begin{array}{c}\text { Konu-Kategori } \\
\text { Illişkisi }\end{array}$ \\
\hline K 1 & Eğitimci/Yazar & El Sanatı ve Turizm İlişkisi & Kategori 3 \\
\hline K 2 & Dölek Köyü Muhtarı & Guduların Üretim Süreçleri & Kategori 2 \\
\hline K 3 & El Sanatı Ustası & Guduların Üretim Süreçleri & Kategori 2 \\
\hline K 4 & Yerel Halk & Guduculuğun Eskiye Göre Durumu & Kategori 1 \\
\hline K 5 & Eğitimci/Yazar & Guduların Kullanım Alanları & Kategori 2 \\
\hline K 6 & El Sanatı Ustası & Guduculuğa Duyulan İlgi & Kategori 1 \\
\hline K 7 & Gazeteci/Yazar & Guduculuğun Ekonomik Boyutu & Kategori 3 \\
\hline
\end{tabular}

Tablo 1'de katılımclardan bilgi alınan temel konulara yer verilmektedir. El sanatı ustaları, yerel halk ve köy muhtarından guduların üretim süreçleri, guduculuğun eskiye göre durumu, guduların kullanım alanları ve guduculuğa gösterilen ilgi düzeyi konularında bilgi alınmışken; eğitimci-yazar katılımcılardan el sanatı-turizm ilişkisi, el sanatının ekonomik değeri konularında bilgi alınmıştır. Ayrıca bilgi alınan temel konuların araştırma kategorileriyle ilişkisi de Tablo 1'de yer almaktadır.

\section{BULGULAR}

Araştırmanın bu kısmında; Gümüşhane ili Dölek Köyü'nde geleneksel olarak üretilen ve "gudu" olarak ifade edilen çömleklerin üretim sürecine, üretilen ürünlerin kapsamına, el sanatının gelecek nesillere aktarılmasında yaşanan güçlüklere ve turizmin "guduculuğun" korunmasında ve gelecek nesillere aktarılmasındaki rolüne ilişkin ortaya çıkan bulgulara yer verilecektir.

\section{Guduculuk El Sanatının Eskiye Göre Durumu ve Gelecek Nesillere Aktarılmasında Yaşanan Güçlükler}

Dölek Köyü'nde guduculuk el sanatı eskiden önemli bir geçim kaynağıydı. Gudu ustaları Dölek Köyü'nde ürettikleri ürünleri bölge illerine götürüp, satmaktaydılar. Geçmiş yıllarda köyün büyük bir kısmının guduculukla geçimini sağladığı söylenebilir. Dölek Köyü guduculuk el sanatı sayesinde çevresindeki köylere kıyasla ekonomik olarak daha iyi durumdaydı. Konuyu bir el sanatı ustası ise şu şekilde ifade etmektedir:

"Biz eski zamanlarda 7-8 vilayete gudu götürüp, satardık. Üretim, günümüzde o kadar azaldı ki; üretilen ürünler Gümü̈shane'nin ihtiyacını bile karşılayamıyor. Önceleri Dölek Köyü'nde yaklaşık 160 hane bu işle uğraşırken, şimdi sadece 10 hane bu işi yapıyor. O zamanlar köylü, neredeyse bütün gelirini bu meslekten elde ediyordu (K2)"

Guduculuğun Dölek Köyü'nün ekonomik yaşamındaki önemini vurgulayan diğer bir el sanatı ustası ise konuyu şöyle açıklamaktadır:

"Köyümüzün geçmiş yıllarda guduculuktan başka geçim kaynağı yoktu. Temel geçim kaynağımız bu işti.

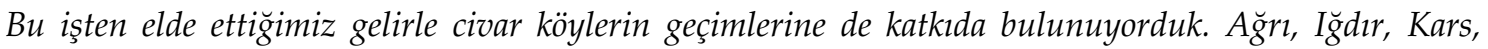
Erzurum, Van, Hakkari ve Erzincan'a kadar atlarla götürdüğ̈̈müz kendi imalatımı olan guduları bu illerde satardık. 1966 yılına kadar köyümüzün yolu yoktu. Atlarla taşıdığımız ürünlerimizi Pirahmet civarında depoluyor, oradan arabalara yükleyerek satıs yapacağımız illere götürüyorduk. Kazandığımız paralarla gittiğimiz yerlerden ihtiyacımız olan kumanyamızı temin ederdik. İhtiyacımızdan fazlasını diğer 
köylere satardık. Bu meslek hiçbir zaman aç bırakmadı. Kendi ihtiyacımızı karşıladıktan sonra, hem Trabzon yaylalarındaki vatandaşlara hem de civar köylerde yaşayanlara yardımda bulunurduk. Ihtiyaç sahiplerinden ekonomik durumu olana parayla satardik, ekonomik durumu olmayana ise para almadan verirdik. En yoğun kıtlık dönemlerinde bile bu meslek sayesinde ekonomik problem yaşamadık (K4)".

Günümüzde guduculuk el sanatına yeterli ilgi gösterilmediği söylenebilir. Özellikle gençlerin guduculuk el sanatına yönelik ilgisizliğinin temel nedenleri arasında; göç, kentleşme, ekonomik faktörler, guduculuğun üretim sürecinde yaşanan güçlükler (toprakların dağlardan getirilmesi) gösterilebilir. Guduculuk el sanatının daha çok orta yaş ve üzeri kadınlar tarafından sürdürüldüğü söylenebilir. Diğer taraftan guduculuk Dölek Köyü'nde sadece 5-10 hane tarafından sürdürülmektedir. Guduculuğa olan ilgisizlik ise bir katılımcı tarafından şu şekilde ifade edilmiştir:

"Bu mesleği yeni nesil öğrenmiyor. Gençlerimiz bu mesleğe eskisi kadar ilgi duymuyor. Yaşanan gö̈çlerden dolayı köyümüzde genç nüfus kalmadı. Bu işin temel geçim kaynağı olarak sürdürüldüğü dönemlerde, bu mesleği her yaştan kadın icra ediyordu. Böyle giderse guduculuk el sanatının fazla bir geleceği yok (K4)"

El sanatının devam ettirilmesinde yaşanan güçlükler ile ilgili belirtilmesi gereken diğer hususlar ise; gudu yapımında kullanılan toprağın dağlardan getirilmesinin güçlüğü (topraklar köyün erkekleri tarafından gerek at, katır gibi hayvanlarla; gerekse kendi sırtlarına yükledikleri sepetlerle getirilmektedir), satış ve pazarlama yetersizliği, guduların sergileneceği uygun mekanların olmaması, yerel halkın birlikte karar alamaması şeklinde ifade edilebilir. Bu doğrultuda ise, guduculuk el sanatına olan ilgisizlik ve meslekte yaşanan güçlükler bir katılımcı tarafından şu şekilde anlatılmaktadır:

"Gelinlerimden kızlarımdan bu işi yapan kimse yok. Hiçbiri bu işi öğrenmek istemedi. Genellikle küçük yaşlarda öğrenilmesi gereken zor bir iş bu. Bu sadece bir kişinin tek başına yapabileceği bir iş değil. Üç veya dört kişinin birlikte yapabileceği bir iş. Köyümüzde hala geçimlerini bu işten temin eden bazı aileler var, ancak eskisi kadar çok değil (K6)"

\section{Guduculuk El Sanatının Üretim Süreci, Kullanım Alanları ve Özgün Nitelikleri}

Dölek Köyü'nde üretilen gudular farklı yerlerden toplanan çeşitli toprakların köye getirilmesi ile başlayan bir süreçtir. Bu süreci toprağın ayıklanması, şekil verilmesi, kurutulması ve fırınlarda pişirilmesi aşamaları takip etmektedir. El sanatı ustaları guduların üretim süreçlerini şu şekilde açıklamaktadır:

"Dağdan gelen çamurlar su ile ıslatılarak, yumuşaması sağlanır. Daha sonra naylon çuvallar üzerinde çiğnenerek hamur haline getirilen çamurlar, taşlardan ayıklanır. Ayıklanan çamurlar el yapımı gurufanın (el yapımı düz tahta) üzerinde şekillendirilir. Göz kararı, el ayarı değişik boyutlarda yapılan gudular kurutulmaya bırakılır. Kurutma işleminden sonra guduların kulpları yapılır ve daha sonra "gogoçlama" (yassı bir taşla zımparalama) işlemine geçilir. Bu aşamadan sonra granzı denilen bir araçla gudunun ağız kısmına şekil verilir. Bütün bu işlemlerden sonra odun ve tezeklerle sarılan gudular tandırda pişirilip soğutulduktan sonra satış için hazır hale getirilir (K2-K3-K4)" 


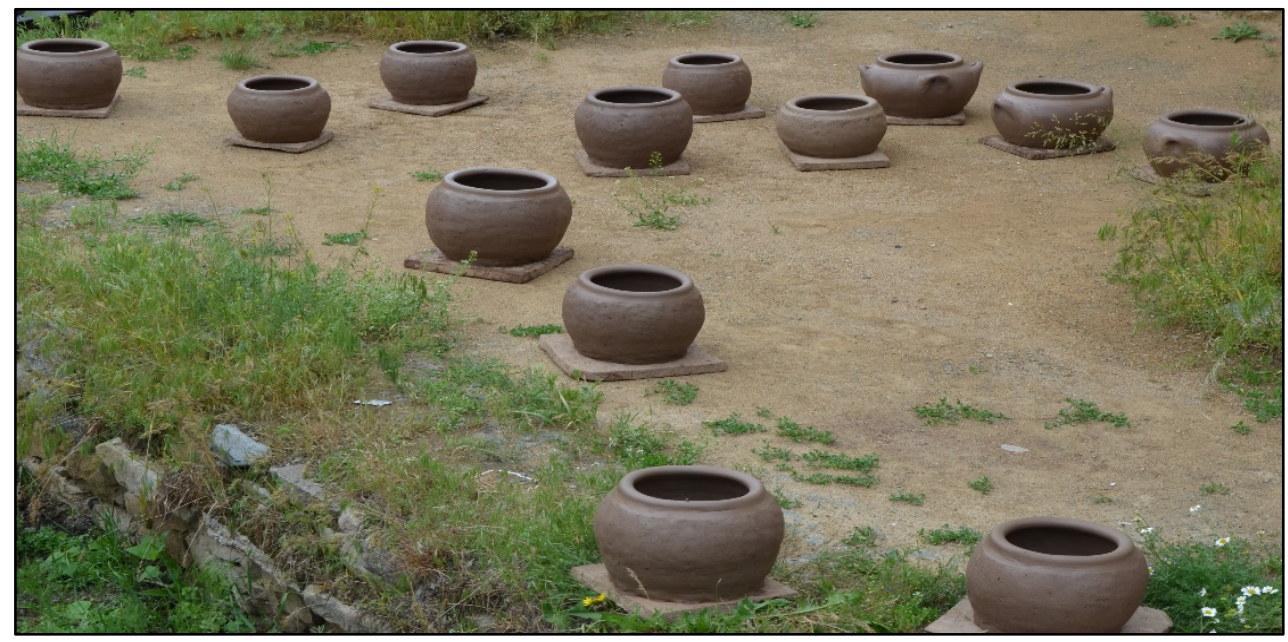

Fotoğraf 2. Gudu Üretim Sürecinde Guduların Kurutulma Aşaması

Kaynak: 21 Haziran 2016 tarihinde gerçekleştirilen uygulama gezisinde yazarlar tarafından fotoğraflanmıştır.

Katılımcıların ifadelerine göre gudular, geçmişten günümüze çeşitli amaçlarla günlük hayatta kullanıma sunulan bir üründür. Gudular günümüzde yemek pişirme amaçlı kullanılmakla beraber, eskiden çeşitli ürünlerin saklanması amacıyla da kullanılmaktaydı. Bir katılımcının buna ilişkin ifadesi ise şu şekildedir:

"Gudularda turşu ve peynir saklanırdı. Ağustos ayında koyulan peynir mart ayına kadar gudularda saklanabiliyordu. Gudular günümüzde daha çok yemek pişirme amaçlı üretiliyor artık (K5)"

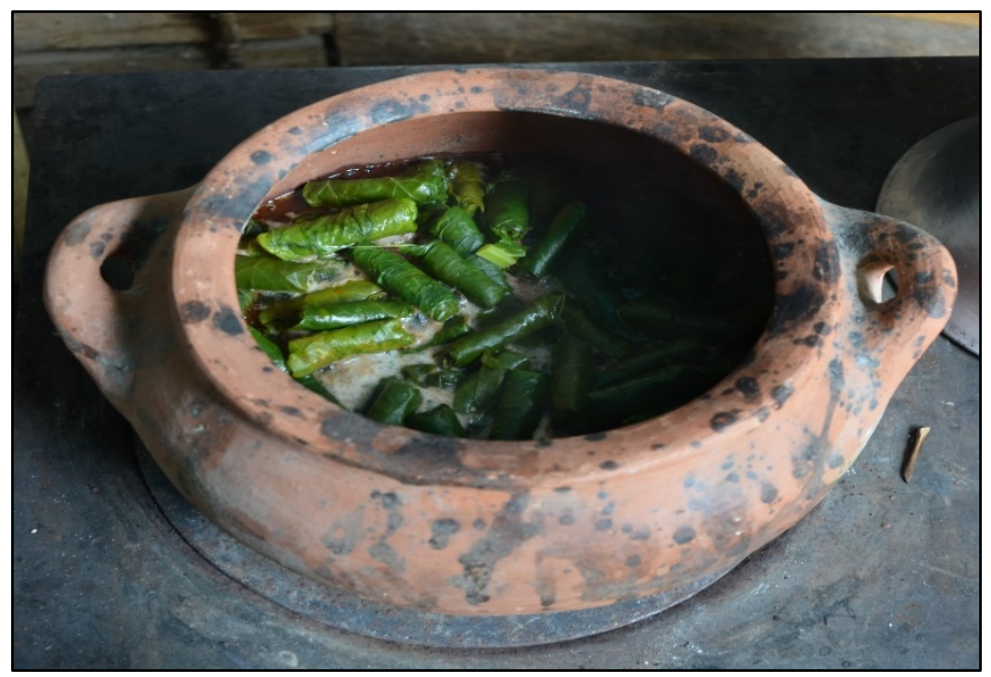

Fotoğraf 3. Kullanıma Hazır Hale Getirilen Gudular

Kaynak: 21 Haziran 2016 tarihinde gerçekleştirilen uygulama gezisinde yazarlar tarafından fotoğraflanmıştır.

Dölek Köÿ̈'nde imal edilen guduların özgün nitelikleri ile ilgili bazı önemli noktalara değinmek yararlı olacaktır. Guduların toprağın kokusunu yemeğe geçirmemesi, sağlam ve dayanıklı olması, üretim sürecinde geleneksel yöntemlerin devam ettirilmesi ve makineleşmeye gidilmemesine bağlı olarak guduların doğallığını koruması Dölek Köyü'nde üretilen guduların en önemli özellikleri olarak vurgulanabilir. 


\section{El Sanatının Korunması ve Gelecek Nesillere Aktarılması İle İlgili Katılımcıların Önerileri ve Bu Noktada Turizmin Rolü}

Birleşmiş Milletler Dünya Turizm Örgütü tarafından 2004 yılında hazırlanan “Sürdürülebilir Turizm Destinasyonları için Gösterge Rehberi" adlı çalışmada "kültürel değerlerin korunması" konusunda birçok farklı gösterge yer almaktadır. Kültürel alan ve yapılar, bu yapılara ilişkin planlanan koruma faaliyetleri, somut ve somut olmayan kültürel miras unsurlarının sürdürülebilir ilkelere göre yaşatılması vb. hususlarda hedef ve göstergeler belirlenerek, korunmasına ilişkin önlemlerin alınmasının gerekliliği vurgulanmaktadır (UNWTO, 2004: 76). Kültürel miras unsurları arasında yer alan geleneksel el sanatlarının geçmişten günümüze unutulma ve kaybolma tehlikesiyle karşı karşıya kaldığı, sürdürülebilir turizm ilkeleri rehberliğinde özünün korunarak yaşatılmasının gerekliliği, gelecek nesillere aktarılmasının önündeki engellerin neler olduğu vb. konular sürdürülebilir turizmin ilgi alanına girmektedir.

Dölek Köyü'nde guduculuk el sanatının korunması ve gelecek nesillere aktarılması ve bu anlamda turizmin rolü ile ilgili olarak katılımcılar birbirinden farklı görüş ve önerilerde bulunmuşlardır. Genel olarak guduculuk el sanatının sürdürülebilmesi için; gençlere ve diğer yaş grubundaki katılımcılara yönelik mesleki eğitim programlarının düzenlenmesi, guduculukla ilgili gerekli yatırımların yapılması (örneğin toprağın getirildiği dağlara yönelik ulaşım imkanlarının iyileştirilmesi), gudu üreticilerinin ekonomik olarak desteklenmesi, guduculuk el sanatında üretim verimliliğini artırmaya yönelik makinelerin kullanılması, guduculuğun devam ettirilmesine yönelik kooperatifleşmeye gidilmesi gibi öneriler getirilmiştir. Bu görüş ve önerilerle ilgili katılımcıların ifadeleri ise özetle şu şekildedir:

"Bu meslekle ilgili ilimizde bir eğitim programı olursa belki ilgi duyan, öğrenmek isteyen gençler çıar da bu meslek devam eder. Mesleğin devam edebilmesi için ise makineleşmeye gidilmesi ve guduculuğun maddi olarak desteklenmesi gerekiyor (K2)"

“Bütün köylü birlik olsa bir kooperatif kurulsa, seri üretime geçilse bu meslekten daha çok aile ekmek yer. Başka bir gelir kaynağının olmadı̆̆g köyümüzde, bu işin zorluğunu gören gençlerimiz köyden büyük şehirlere göç edip gittiler. Guduculuğun devam ettirilebilmesi için gerekli adımların atılması gerekiyor $(K 4)^{\prime \prime}$

"Gudu yapımında çalı̧̧an bayanların kazanç elde etmesi gerekiyor bu işi devam ettirebilmesi için. Bu ürünleri satabileceğimiz pazar bulmalıyız ki insanlar guduları üretmek için istekli olsun. Ayrıca bu el sanatını devam ettiren kadınlar bu işi tek başlarına yürütemezler. Her açıdan desteklenmeleri gerekir (K7)"

Ayrıca bu el sanatının devam ettirilebilmesi noktasında turizmin nasıl bir rol üstleneceğine ilişkin katılımcıların görüş ve önerileri kendi ifadeleriyle şu şekildedir:

“Gümüşhane'nin kültürünü yansitan yaşayan müze, toplum müzesi mesela gudu müzesi kurularak Gümüşhane kültürrü turizme kazandırılabilir. 1950 sokă̆ı, 1960 sokağı, 1970 sokağı uygun senaryolarla yaşayan müze şeklinde canlandırlabilir (K1)"

"Bu mesleğin gelecek nesillere aktarllabilmesi için öncelikle yaşanan göçleri durdurmak, giden genç nüfusu geri getirmek gerekiyor. Bunun için de bu işten elde edilen geliri artırmak şart. Bu noktada ise turizmin önemli katklları olabilir. Turizmle birlikte bilinirliği artacak olan bu meslek gelecek nesillere aktarlabilir (K2)"

"Guduculukla ilgili gerekli yatırımlar yapılırsa, köyümüze yerli yabancı birçok turist gelir. Sadece gudu almak için değil, aynı zamanda nasıl üretildiğini, bu işi kimlerin yaptığını, hangi aşamalardan geçtĭ̆ini görmek için de gelenler olabilir (K4)" 


\section{SONUÇ VE ÖNERILER}

Kültürel değerlerin giderek yok olmaya başladığı günümüzde en büyük olumsuz etkiyi, ancak nesilden nesile aktarılarak yaşatılması mümkün olabilen somut olmayan kültürel miras unsurları görmektedir. Somut olmayan kültürel miras unsurlarının doğrudan toplumun yaşantı ve geleneklerini yansıtması, bu unsurları oldukça değerli kılan bir özelliktir. Bu değerlerin gelecek nesillere aktarılmaması ya da kayıt altına alınmaması durumunda ise unutulması kaçınılmazdır. Anadolu'nun dört bir yanında yok olma tehlikesiyle karşı karşıya olan birçok somut olmayan kültürel miras unsuru mevcuttur. Bunlardan en önemlisi ise geleneksel el sanatlarıdır. Gümüşhane merkeze bağlı Dölek Köyü'nde artık sınırlı düzeyde üretimi gerçekleştirilmekte olan guduculuk el sanatı da yok olma tehlikesiyle karşı karşıyadır. Bu noktada turizm, guduculuk el sanatının canlandırılması ve gelecek nesillere aktarılmasında önemli bir araç olarak değerlendirilebilir.

Son dönemlerde bu değerlerin korunması ve gelecek nesillere aktarılmasında turizm önemli bir rol oynayabilmektedir. Bu konu ise sürdürülebilir turizm kapsamında tartışılagelen bir konudur. Sürdürülebilir turizm, tüm kültürel değerlerin turizm etkinlikleri sayesinde yeniden canlandırılacağını ve sürdürülebilir ilkeler çerçevesinde korunup gelişeceğini öngörmektedir. Yerel halk bu sayede kültürel benliğine sahip çıkarak toplumsal değerlerinin yaşatılması için çaba harcayacak, turizmden ekonomik ve kültürel anlamda azami düzeyde yararlanmaya çalışacaktır. Ancak bu noktada yerel halkın ekonomik kazanç elde etme beklentisinden önce, kültürel değerlerine sahip çıkma bilinciyle hareket etmesi çok daha önem arz etmektedir.

Çalışmada ortaya çıkan sonuçlar incelendiğinde, Gümüşhane ili Dölek Köyü'nde sürdürülmekte olan gudu el sanatının korunması ve gelecek nesillere aktarılması anlamında birtakım problemler yaşandığı görülmektedir. Yaşanan problemlerin en önemli nedeni, guduculuğun üretim sürecinde yaşanan güçlükler ile ekonomik değeri arasında bir dengenin kurulamamasıdır. Gudunun hammaddesini oluşturan toprakların farklı yerlerden zorlu koşullar altında tedarik edilmesi ve oldukça zahmetli bir üretim sürecine tabi tutulması, buna mukabil ekonomik kazancının emeğinin karşılığını verememesi guduculuk el sanatının gençler tarafından ilgi görmemesinin en önemli sebebidir. Benzer şekilde Özkul Fındık ve Köşklü (2013: 56) tarafından yapılan araştırmada Dölek Köyü'ndeki genç kızların guduculuğu yapmak istememeleri ve dolayısıyla öğrenmemeleri nedeniyle gelecekte köydeki guduculuğun yok olma tehlikesiyle karşı karşıya kalacağı belirtilmektedir. Bu noktada, gençlerin bu el sanatını öğrenmesini sağlayacak eğitim programlarının düzenlenmesi ve bu kursların tamamlanmasının ardından kursiyerlerin kendi özel girişimlerinin desteklenmesi gerektiği söylenebilir.

Guduculuk el sanatının üretimi ve kullanımının özendirilmesine yönelik çabalar oldukça önemlidir. Guduculuğun üretiminin özendirilmesi ile birlikte, kullanımının da özendirilmesine yönelik tüketicilerin bilinçlendirilmesi gerekmektedir. Turistlerin doğal üretim koşullarından geçmiş olan gudularda saklanmış ve pişirilmiş yiyecekleri test etmeleri sağlanmalıdır. Bu noktada illerin yöresel ürünlerinin tanıtıldığı tanıtım fuarlarının etkin bir rol üstleneceği açıktır. Ayrıca Dölek Köyü'nde üretimin yaygınlaştırılmasına yönelik Türkfiliz'in (1997: 11) de vurguladığ gibi kooperatifleşmeye gidilmesi bir seçenek olarak görülebilir. Dölek Köyü için önemli bir ekonomik kaynak olarak değerlendirilebilecek guduculuğun pazarlama sorunlarının bulunduğu söylenebilir. Kooperatifleşme ile pazarlama sorunlarının çözüleceği düşünülmektedir.

Guduculuğun korunabilmesi ve gelecekte de sürdürülebilmesi için; doğal üretim koşullarının, üretim sürecinin ve üretim için gerekli olan hammaddelerin (toprakların) mümkün olduğunca korunması gerekmektedir. Turizm etkinliklerinin hız kazanması ve talebin artışına bağlı olarak seri üretime geçilmesi, ürünün doğallığını yitirmesine yol açabilecektir. Bu noktada turizm 
etkinlikleri kapsamında sunulacak ürünlerin doğallığını koruması için el emeği ile üretiminin devam ettirilmesi ve gudunun hammaddesini oluşturan toprakların aşırı ve bilinçsizce kullanımının önüne geçilmesine yönelik önlemler alınması guduculuğun sürdürülebilir turizm ilkeleri çerçevesinde korunmasına imkan verebilir.

Guduculuk el sanatı ile birlikte; bakırcılık, demircilik, ahşap işlemeciliği, taş işlemeciliği, ipek halı dokumacılığı, zilli ve ala kilim dokumacılığı, zil yapımı gibi Gümüşhane'ye özgü el sanatı ve zanaatların da sürdürülebilir turizm ilkeleri çerçevesinde korunması ve gelecek nesillere aktarılması gerekmektedir. Bu noktada ilgili el sanatı ve zanaat alanlarında geleneksel üretim süreçlerinin ve usta-çırak ilişkisine dayanan geleneksel eğitim anlayışının mümkün olduğunca korunması ve devam ettirilmesi, gençlerin el sanatı ve zanaat unsurlarının üretimine sosyal, kültürel ve ekonomik anlamda özendirilmeleri, söz konusu el sanatı ve zanaatların il tanıtım günleri ve tanıtım fuarları gibi farklı platformlarda tanıtımının ve pazarlanmasının sağlanması ve kooperatifleşmeye gidilmesi guduculuk el sanatı başta olmak üzere Gümüşhane'ye özgü tüm el sanatı ve zanaat unsurlarının sürdürülebilirliğinin sağlanmasına yönelik getirilebilecek önerilerdir.

Ayrıca Gümüşhane'ye özgü söz konusu somut olmayan kültürel miras unsurlarının, somut kültürel miras unsurları ile birlikte bütünleşik bir ürün olarak turistik tüketicilere sunulması önerilebilir. Nitekim her turistik tüketici, yalnızca gudu üretimini deneyimlemek için Dölek Köyü'nü ziyaret etmeyebilir. Gudu üretimini deneyimlemek için Dölek Köyü'nü ziyaret etmek isteyenler olabileceği gibi, bazı turistler için satın almak üzere söz konusu ürüne en kısa sürede ulaşabilmeleri yeterli olacaktır. Bu nedenle Gümüşhane'nin çekicilik arz eden diğer destinasyonları da tur güzergahlarına dahil edilmeli ve turistlerin Gümüşhane'nin somut kültürel miras unsurları ve doğal çekicilikleri ile birlikte, somut olmayan kültürel miras unsurlarını da deneyimlemeleri sağlanmalıdır. Örneğin, Gümüşhane Karaca Mağarası çevresinde gerçekleştirilen ancak Gümüşhane'ye özgü el sanatı va zanaatlarının çok fazla yer bulmadı ğı hediyelik eşya üretimi ve satışları gibi; gudular, bakır işlemeleri, ahşaptan yapılmış ürünler, zilli kilim ve ala kilim gibi ürünlerin satışları da Karaca Mağarası'nda ve Gümüşhane'nin diğer destinasyonlarında gerçekleştirilebilir.

Diğer taraftan guduculuk el sanatının ekonomik çekiciliğini artırmaya yönelik çabalarla birlikte, gençlerin kendi kültürel birikimlerine sahip çıabilmeleri anlamında bilinçlendirilmeleri de gerekmektedir. Bu noktada; geçmişiyle duygusal bağlarını tamamen kopararak yalnızca ekonomik bir araç olarak guduculuğu ve diğer el sanatlarını devam ettiren bir nesilden ziyade, turizm vasıtasıyla değerlerine sahip çıkan ve sahip olduğu bu değerleri koruyup geliştirerek farklı kültürlerle ve gelecek nesillerle buluşturmayı ilke edinen bilinçli bir nesil oluşturmak oldukça önemlidir.

\section{KAYNAKÇA}

Akyol, P. K. (2012). Kullanım Şekilleri ve Geleneğiyle Kültürümüzde Toprak. Çevrimiçi Tematik Türkoloji Dergisi, 4(1): 316-333.

Albayrak, M. (2013). Kelkit Vadisi Bölgesinde Görülen Beş Zamanlı Halk Oyunları Ezgilerinin Melodik ve Ritimsel Yapılarının Örnekler İle İncelenmesi. Yayınlanmamış Yüksek Lisans Tezi, İstanbul Teknik Üniversitesi Sosyal Bilimler Enstitüsü, İstanbul.

Baykal, F. (1990). Kırsal Yerleşim Coğrafyası Açısından Bir Araştırma: Gökeyüp Köyü (Salihli/Manisa) ve İlkel Çömlekçiliğin Köy Ekonomisindeki Yeri. Ege Coğrafya Dergisi, 5(1): 5574.

Beyhan, Ş. G. ve Ünügür, S. M. (2005). Çağdaş Gereksinimler Bağlamında Sürdürülebilir Turizm ve Kimlik Modeli. İstanbul Teknik Üniversitesi Dergisi, 4(2): 79-87. 
Buner, Ö. P. ve Okca, A. K. (2016). Gölbaşı (Ankara) Çömlekçiliğinin Korunması, Sorunları ve Çözüm Önerileri. Güzel Sanatlar Fakültesi Sanat Dergisi, 9(17): 278-296.

Butler, R. W. (1999). Sustainable Tourism: A State-of-the-Art Review. Tourism Geographies, 1(1): 725.

Can, M. (2013). Geleneksel Türk El Sanatlarının Turizme ve Ekonomiye Katkısı. Sosyal ve Beşeri Bilimler Dergisi, 5(2): 259-266.

Ceylan, S. (2014). Mamak (Çanaklı) Beldesinde (Ağlasun-Burdur) Geleneksel Yöntemlerle Sürdürülen Toprak Kap Üretiminin Kırsal Turizm Bağlamında İrdelenmesi. Doğu Coğrafya Dergisi, 19(32): 231-242.

Choi, H. S. C. and Sirakaya, E. (2005). Measuring Residents' Attitude Toward Sustainable Tourism: Development of Sustainable Tourism Attitude Scale. Journal of Travel Research, 43(4): 380-394.

Clarke, J. (1997). A Framework of Approaches to Sustainable Tourism. Journal of Sustainable Tourism, 5(3): 224-233.

Çalık, İ. ve Ödemiş, M. (2015). Somut Olmayan Kültürel Miras Unsurlarının Sürdürülebilir Turizm Kapsamında Değerlendirilmesi: Gümüşhane İli Örneği, 16. Ulusal Turizm Kongresi, Çanakkale Üniversitesi 12-15 Kasım 2015, Çanakkale.

Çalık, İ., Kaya, F., Akdu, U., Sezerel, H., Aras, G. ve Köstepen, A. (2013). Gümüşhane İli Turizm Potansiyeli, (Editör) Günaydın, İ., Gümüşhane Üniversitesi Yayınları, Gümüşhane, s. 12.

Demirbulat, Ö. G., Özdemir, S. S. ve Bozok, D. (2015). El Sanatları ve Turizm İlişkisi Çerçevesinde Türk Hah Dokumacılığının UNESCO Somut Olmayan Kültürel Miras Listesinde Yer Alan Örnekler Doğrultusunda Değerlendirilmesi, 14. Geleneksel Turizm Paneli, 16 Nisan 2015, Sakarya.

Er, B. ve Hünerel, Z. S. (2011). Turistik Bir Bölge Olan Nevşehir İlinin Yöredeki El Sanatlarına Katkısı, I. Uluslararası Nevşehir Tarih ve Kültür Sempozyumu, 16-19 Kasım 2011, Nevşehir.

Erdener, H. (1997). Gümüşhane'nin Seyir Defteri. Ankara: Teknik Matbaacıllk.

Gümüşhane Valiliği (1999). Cumhuriyet'in 75. Yılında Gümüşhane.

Gümüşhane Valiliği (2009). Gümüşhane Çevre Durum Raporu. [Online] http://gumushane.ormansu.gov.tr/Gumushane/New\%20folder\%20(1)/G\%C3\%BCm\%C3\%BC\% C5\%9Fhane\%20\%C4\%B0li\%20\%C3\%87evre\%20Durum\%20Raporu.pdf [Erişim Tarihi: 08.04.2019].

Hardy, A. L. and Beeton, R. J. S. (2001). Sustainable Tourism or Maintainable Tourism: Managing Resources for More Than Average Outcomes. Journal of Sustainable Tourism, 9(3): 168-192.

Hassan, S. S. (2000). Determinants of Market Competitiveness in an Environmentally Sustainable Tourism Industry. Journal of Travel Research, 38(3): 239-245.

Holfstein, A. J. and Gubrium, F. J. (1999). Active Interviewing, (Editors) Bryman, A. and Burgess, R. G.: Qualitative Research içinde, London: Sage Publications.

Hunter, C. (1997). Sustainable Tourism As an Adaptive Paradigm. Annals of Tourism Research, 24(4): 850-867.

Kurin, R. (2004). Safeguarding Intangible Cultural Heritage in the 2003 UNESCO Convention: A Critical Appraisal. Museum International, 56(1-2): 66-77. 
Labadi, S. (2013). UNESCO, Cultural Heritage, and Outstanding Universal Value: Value-Based Analysis of the World Heritage and Intangible Cultural Heritage Conventions, (Editors) Hodder, I. and Preucel, R. W., Lanham: AltaMira Press.

Leimgruber, W. (2010). Switzerland and The UNESCO Convention on Intangible Cultural Heritage. Journal of Folklore Research: An International Journal of Folklore and Ethnomusicology, 47(12): 161-196.

Onuk, T. ve Akpınarlı, F. (2004). Somut Olmayan Kültürel Mirasımızdan El Sanatları. Bilge Dergisi, 11(11): 4-6.

Öter, Z. ve Ünal, E. (2011). Somut Olmayan Kültürel Miras ve Turizm Etkileşiminin Beypazarı İlçesinde Yerel Ekonomiye Katkları, The 8th International Turkish Folklore Congress, 21-24 Kasım 2011, İzmir.

Özkul, N. Findık ve Köşklü, Z. (2013). Gümüşhane/Dölek Köyünde Çömlekçilik. Atatürk Üniversitesi Güzel Sanatlar Enstitüsü Dergisi, Sayı: 31: 51-67.

T.C. Kültür ve Turizm Bakanlığı (2017). Somut Olmayan Kültürel Mirasın Korunması Sözleşmesi Hakkında. [Online] http://aregem.kulturturizm.gov.tr/TR,50837/somut-olmayan-kulturelmirasin-korunmasi-sozlesmesi-hak-.html [Erişim Tarihi: 14.09.2017].

T.C. Turizm Bakanlığı (Yatırımlar Genel Müdürlüğü) ve Gümüşhane Valiliği (1994). Gümüşhane İli Turizm Envanteri ve Turizm Geliştirme Planı, Ağustos.

Türker, A. ve Çelik, İ. (2012). Somut Olmayan Kültürel Miras Unsurlarının Turistik Ürün Olarak Geliştirilmesine Yönelik Alternatif Öneriler. Yeni Fikir Dergisi, Sayı: 9: 86-98.

Türkfiliz, H. (1997). Bir Gümüşhane Klasiği Gudu. Kültür Vadisi Gümüşhane Dergisi, Sayı: 12: 1011.

UNESCO (1989). Recommendation on the Safeguarding of Traditional Culture and Folklore, Records of the General Conference, Twenty-Fifth Session, October 17-November 16, Paris. [Online] https://unesdoc.unesco.org/ark:/48223/pf0000084696.page=242 [Erişim Tarihi: 08.07.2019].

UNESCO (2003). Text of the Convention for the Safeguarding of the Intangible Cultural Heritage. [Online] https://ich.unesco.org/en/convention [Erişim Tarihi: 08.07.2019].

UNWTO. (2004). Indicators of Sustainable Development for Tourism Destinations: A Guidebook. Madrid, Spain.

Ülker, T., Yılmaz, N., Kazanc1, Ş. ve Doğru E. (2011). Gümüşhane Halk Kültürü-2, Gümüşhane Yöresinde Ticari Hayat, Gümüşhane: Gündüz Ofset Matbaacılık ve Yayıncılık, s. 387-415.

Yıldırım, A. ve Şimşek, H. (2008). Sosyal Bilimlerde Nitel Araştırma Yöntemleri. Ankara: Seçkin Yayınevi.

\section{Kaynak Kişiler}

1. Menşure ARI (El Sanatı Ustası)

2. Hasan PİR (Eğitimci/Yazar)

3. Turan TUĞLU (Gazeteci)

4. Yusuf SADIK (Gazeteci/Yazar)

5. Hatice FINDIKLI (El Sanatı Ustası)

6. Süleyman Bey (Yerel Halk)

7. İlhan ÇOLAK (Köy Muhtarı) 